\title{
Molybdenum Induces the Expression of a Protein Containing a New Heterometallic Mo-Fe Cluster in Desulfovibrio alaskensis ${ }^{\dagger}$
}

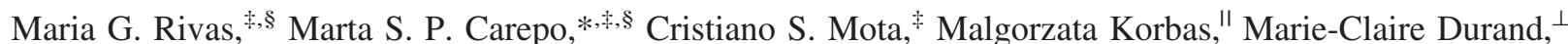 \\ Ana T. Lopes, ${ }^{\ddagger}$ Carlos D. Brondino, ${ }^{\#}$ Alice S. Pereira, ${ }^{\star}$ Graham N. George, ${ }^{\prime \prime}$ Alain Dolla, ${ }^{\perp}$ José J. G. Moura, ${ }^{\star}$ and \\ Isabel Moura*** \\ REQUIMTE/CQFB, Departamento de Química, Faculdade de Ciências e Tecnologia, Universidade Nova de Lisboa, \\ 2829-516 Caparica, Portugal, Department of Anatomy and Cell Biology, University of Saskatchewan, \\ Saskatoon, S7N 5E5, Canada, Unité Interactions et Modulateurs de Réponses, IBSM-CNRS, 31 chemin Joseph Aiguier, \\ 13402 Marseille cedex 20, France, and Physics Department, Facultad de Bioquímica y Ciencias Biológicas, Universidad \\ Nacional del Litoral, 3000 Santa Fe, Argentina
}

Received September 17, 2008; Revised Manuscript Received December 12, 2008

\begin{abstract}
The characterization of a novel Mo-Fe protein (MorP) associated with a system that responds to Mo in Desulfovibrio alaskensis is reported. Biochemical characterization shows that MorP is a periplasmic homomultimer of high molecular weight $(260 \pm 13 \mathrm{kDa})$ consisting of 16-18 monomers of $15321.1 \pm$ $0.5 \mathrm{Da}$. The UV/visible absorption spectrum of the as-isolated protein shows absorption peaks around 280,320 , and $570 \mathrm{~nm}$ with extinction coefficients of 18700,12800 , and $5000 \mathrm{M}^{-1} \mathrm{~cm}^{-1}$, respectively. Metal content, EXAFS data and DFT calculations support the presence of a Mo-2S-[2Fe-2S]-2S-Mo cluster never reported before. Analysis of the available genomes from Desulfovibrio species shows that the MorP encoding gene is located downstream of a sensor and a regulator gene. This type of gene arrangement, called two component system, is used by the cell to regulate diverse physiological processes in response to changes in environmental conditions. Increase of both gene expression and protein production was observed when cells were cultured in the presence of $45 \mu \mathrm{M}$ molybdenum. Involvement of this system in Mo tolerance of sulfate reducing bacteria is proposed.
\end{abstract}

Molybdenum is the only second row transition element known to be important in biology. It is required for the catalytic activity of a number of important enzymes found in bacteria, animals and plants (1). Molybdenum enzymes, with the notable exception of the nitrogenase system, contain Mo coordinated to one or two dithiolene groups from pyranopterin molecules, and to a variable number of ligands such as oxo, hydroxo, water, serine, aspartic acid, cysteines, and selenocysteines (2). The nitrogenase system has one of the most complex arrangements of heterometallic active sites, the FeMoco-cofactor. This center contains one [4Fe-3S] and [1Mo-3Fe-3S] bridged by three inorganic sulfurs and a ligand

\footnotetext{
${ }^{\dagger}$ This work was financially supported by Fundação para a Ciência e Tecnologia (POCI/QUI/55350/2004). M.G.R. and C.S.M. thank FCT for Grants SFRH/BPD/29577/2006 and SFRH/BD/32478/2006, respectively. C.D.B. is a member of the CONICET (Argentina). Portions of this work were carried out at the Stanford Synchrotron Radiation Laboratory, which is funded by the U.S. DOE, Office of Basic Energy Sciences and Office of Biological and Environmental Sciences, and the NIH, NCRR. Research at the University of Saskatchewan was supported by the Canadian Institutes of Health Research, a Canada Research Chair award (G.N.G.) and the Natural Sciences and Engineering Research Council Canada.

* Address correspondence to these authors. Fax: + 351-21-2948550. Phone: +351-21-2948381.E-mail: isa@dq.fct.unl.pt, marta.carepo@ dq.fct.unl.pt.

¥ Universidade Nova de Lisboa.

$\S$ Both of these authors contributed equally to this work.

"University of Saskatchewan.

${ }^{\perp}$ IBSM-CNRS.

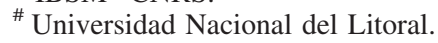

whose nature $(\mathrm{C}, \mathrm{N}$, or $\mathrm{O})$ is still a matter of discussion. The molybdenum is hexacoordinated by two oxygen atoms from a homocitrate molecule, one nitrogen from a His residue and three inorganic sulfurs bridging the Mo atom to the three $\mathrm{Fe}(3-5)$. Another type of molybdenum protein is the orange protein from Desulfovibrio gigas that contains an approximately linear mixed metal sulfide cluster $\left[\mathrm{S}_{2} \mathrm{MoS}_{2} \mathrm{CuS}_{2}\right.$ $\left.\mathrm{MoS}_{2}\right]^{3-}(6,7)$. The function of this protein is still unknown, but there is evidence suggesting that it could be involved in changes in lifestyle from syntrophic to sulfate reducer (8).

Mo in the environment is available for the cells in the form of molybdate compounds and therefore can be incorporated in Mo-proteins through mechanisms for Mo transport, homeostasis and molybdenum cofactor biosynthesis. In Escherichia coli the modABCD operon codes for the high affinity molybdate uptake system related to an ATP-binding cassette (ABC) transporter motif, in which $\bmod A, \bmod B$ and modC encode a molybdate-periplasmic binding protein (a molbindin protein), a membrane channel forming protein (permease) and an ATP energizer, respectively. $\bmod D$ encodes a 231 amino acid protein of unknown function $(9-11)$. The ModE protein, encoded by a separated gene, is a transcriptional regulator that functions as a molybdate sensor and regulates transcription of several operons including $\bmod A B C D(12,13)$.

Molybdate-binding proteins coded by the mo-locus are responsible for cofactor biosynthesis of the mononuclear Mo enzymes. These proteins (Mod/Mop proteins) contain mol- 
bindin-like domains that bind tetrahedral molybdate through hydrogen bonds, as sulfate in sulfate-binding proteins. Aside from the ModABC proteins, the Azotobacter vinelandii genome codifies for ModG which is able to bind up to 8 Mo atoms (14). A. vinelandii also possesses a different molybdenum protein called Mo storage protein which is functionally related to nitrogen fixation and supplies nitrogenase enzymatic system with Mo. This protein is able to store at least 90 Mo atoms per protein and EXAFS ${ }^{1}$ data support the presence of a Mo-oxide aggregate structurally related to heptamolybdate (15).

Although the Desulfovibrio genus possesses several molybdenum enzymes and the complete genomes sequenced so far predict the presence of $\bmod A B C$ operon (16), there are no reports characterizing the systems involved in Mo uptake and regulation. Sulfate reducing bacteria use sulfate as terminal electron acceptor for respiration. Since molybdate is a sulfate analogue, high molybdate concentrations result in molybdate binding to ATP sulfurylase preventing sulfate activation and thereby inhibiting the respiratory chain (17). Thus, similarly to other transition metals, high concentrations of Mo are damaging for cells and bacteria need to carefully control the level of available metal.

In this paper we report the characterization of a new protein from $D$. alaskensis containing a novel heterometallic $\mathrm{MoFe}$ cluster. This protein represents the first system associated with molybdenum response in sulfate reducing bacteria. Since its expression responds to Mo we have called it molybdenum response associated protein (MorP).

\section{EXPERIMENTAL PROCEDURES}

1. Bacterial Strain, Culture Media, and Growth Conditions. D. alaskensis cells were grown at $37{ }^{\circ} \mathrm{C}$ under anaerobic conditions in medium $\mathrm{C}$ from Postgate (18). To evaluate the response of $D$. alaskensis to different metals, cells $(100 \mathrm{~mL})$ were grown in medium $\mathrm{C}$ supplemented with solutions containing one of each metal compound $\left[\mathrm{CuCl}_{2} \cdot 2 \mathrm{H}_{2} \mathrm{O}\right](\mathrm{Merck}), \quad\left[\mathrm{FeCl}_{2} \cdot 4 \mathrm{H}_{2} \mathrm{O}\right]$ (Fluka), $\left[\mathrm{Na}_{2}-\right.$ $\left.\mathrm{MoO}_{4} \cdot 2 \mathrm{H}_{2} \mathrm{O}\right](\mathrm{Merck}),\left[\mathrm{Na}_{2} \mathrm{WO}_{4} \cdot 2 \mathrm{H}_{2} \mathrm{O}\right](\mathrm{Sigma})$ or $\left[\mathrm{ZnCl}_{2}\right]$ (Merck) to a final metal concentration of $45 \mu \mathrm{M}$. Late log phase cells were harvested by centrifugation $(7000 \mathrm{~g}$ for 15 min at $4{ }^{\circ} \mathrm{C}$ ) and the pellet resuspended to a cell density of $1 \mathrm{~g}$ of cells (wet weight) per $\mathrm{mL}$ of buffer $(10 \mathrm{mM}$ TrisHCI pH 7.6). The cell suspension was then subjected to 4 freeze-thaw cycles and centrifuged at $7000 \mathrm{~g}$ for $40 \mathrm{~min}$ to obtain a soluble extract. Finally, the electrophoretic pattern for each condition was analyzed by $15 \%$ tricine SDS-PAGE. Gels were stained with Coomassie blue.

In the case of $\mathrm{Mo}$, several $\mathrm{Na}_{2} \mathrm{MoO}_{4} \cdot 2 \mathrm{H}_{2} \mathrm{O}$ concentrations were added to medium $\mathrm{C}(0.5,2.0,5.0,10,20$, and $45 \mu \mathrm{M})$ and cellular extracts were prepared as explained above.

2. Protein Identification by MALDI-TOF Mass Spectrometry. For protein identification, stained protein-bands were cut off the gel and in-gel digested by trypsin. Peptide mass fingerprint analysis was performed using matrix assisted laser

\footnotetext{
${ }^{1}$ Abbreviations: D., Desulfovibrio; DFT, density functional theory; EXAFS, extended X-ray absorption fine structure; MorP/R/S, molybdenum response associated protein/regulator/sensor; RT-PCR, real time polymerase chain reaction; XAS, X-ray absorption spectroscopy; zraP/ $\mathrm{R} / \mathrm{S}$, zinc response associated protein/regulator/sensor.
}

desorption/ionization time-of-flight mass as previously described (19).

3. Purification Procedures. D. alaskensis cells grown in medium C (300 L) supplemented with $45 \mu \mathrm{M}$ of Mo were collected at the end of logarithmic phase by centrifugation at $8000 \mathrm{~g}$ for $15 \mathrm{~min}$ at $4{ }^{\circ} \mathrm{C}$ (Beckman Avanti J-25 centrifuge). Enriched periplasmic fraction was obtained following protocol described by Brondino et al. (20). Pellet of cells was resuspended in $10 \mathrm{mM}$ Tris- $\mathrm{HCl}$ buffer and incubated for $1 \mathrm{~h}$ at $4{ }^{\circ} \mathrm{C}$. Cell-free extracts were obtained by centrifugation at $5000 \mathrm{~g}$ for $40 \mathrm{~min}$. The supernatant was collected, dialyzed overnight against $10 \mathrm{mM}$ Tris- $\mathrm{HCl}$ and loaded onto an anionic exchange column (DEAE 52 cellulose, Whatman $5 \times 45 \mathrm{~cm}$ ) equilibrated with the same buffer. The fraction containing MorP was collected in the flowthrough. The next chromatographic step was performed on hydroxylapatite (HTP) column equilibrated with the same buffer. Proteins were eluted using a $\mathrm{KH}_{2} \mathrm{PO}_{4} / \mathrm{K}_{2} \mathrm{HPO}_{4}$ buffer gradient $(5-500 \mathrm{mM})$. MorP protein was eluted at $150 \mathrm{mM}$ and judged pure by SDS-PAGE. All the purification procedures were performed aerobically at $4{ }^{\circ} \mathrm{C}$ and buffers were all adjusted at $\mathrm{pH}$ 7.6. The protein purity after each step was followed by UV-visible spectroscopy and $15 \%$ tricine SDS-PAGE.

4. Protein, Metal and Labile Sulfide Quantification. Quantification of protein was carried out using Bicinchoninic Acid Kit (Sigma) with bovine serum albumin as standard protein.

The presence of $\mathrm{Co}, \mathrm{Ni}, \mathrm{Zn}, \mathrm{Mo}, \mathrm{W}, \mathrm{Cu}$ and $\mathrm{Fe}$ was tested by inductively coupled plasma emission analysis in a JobinYvon (Ultima) instrument using the Reagecom 23 ICP multielements as standard solution in a concentration range from 0.05 to $6 \mathrm{ppm}$.

Labile sulfide was determined according to the modified method of Fogo (21). Sodium sulfide nonahydrate quantified by iodometric titration was used as standard.

5. Molecular Mass Determination and Subunit Composition. The molecular mass of the as-isolated protein was determined by gel filtration chromatography using a Superdex 200 column $(1 \times 30 \mathrm{~cm})$ (Pharmacia) equilibrated in $50 \mathrm{mM}$ potassium phosphate, $150 \mathrm{mM} \mathrm{NaCl}(\mathrm{pH} \mathrm{7.6)}$ with a flow rate of $0.5 \mathrm{~mL} / \mathrm{min}$. A volume of $200 \mu \mathrm{L}$ of protein or standard was applied. The standards were aprotinin $(6.5 \mathrm{kDa})$, cytochrome c (12.4 kDa), ovalbumin (47.2 kDa), aldolase $(158 \mathrm{kDa})$, catalase $(232 \mathrm{kDa})$ and ferritin $(440 \mathrm{kDa})$ from Amersham Pharmacia.

Molecular weight of MorP protein subunits was determined using a matrix-assisted laser desorption ionization time of flight (MALDI-TOF) mass spectrometer equipped with a nitrogen laser radiating at $337 \mathrm{~nm}$ (Applied Biosystems, Foster City, USA, model voyager DE-PRO biospectrometry workstation). A volume of $10 \mu \mathrm{L}$ of salt free sample containing approximately $10 \mathrm{pmol}$ of protein was mixed with $10 \mu \mathrm{L}$ of matrix solution (10 mg of $\alpha$-cyano-4-hydroxycinnamicacid dissolved in $1 \mathrm{~mL}$ of $\mathrm{H}_{2} \mathrm{O}$ /acetonitrile/TFA). Then, $1 \mu \mathrm{L}$ of sample was spotted and analyzed. Three external calibrations were performed using apomyoglobin, aldolase and bovine serum albumin with $m / z$ 16952, 39223 and 66469, respectively.

6. N-Terminal and DNA Sequencing. N-Terminal sequence was determined by automated Edman degradation in an Applied Biosystem model 477A protein sequencer coupled to an Applied Biosystem 120 analyzer according to 
Table 1: Nucleotide Sequence of the Primers Used in This Study

\begin{tabular}{lll}
\hline \multicolumn{1}{c}{ name } & \multicolumn{1}{c}{ oligonucleotide sequence $\left(5^{\prime} \rightarrow 3^{\prime}\right)$} & application and description \\
\hline SDDE0109UP & CGATATTGCTTCATGTGCGTGTATGG & DNA sequencing of MorP \\
SDDE0109DOWN & CGATGTCATCAGGTCGTAAAATTCACG & RT-PCR primers for MorP \\
DDE0109UP & GCGGTACGTTGTTTCTGGAT & \\
DDE0109DOWN & TTGAGCCGGTAAAACAGGTC & RT-PCR primers for MorR \\
DDE0111UP & ATTTTTGTCTGGCAGCAGT & RT-PCR primers 16S \\
DDE0111DOWN & TCGGCCACAATCTTGTCATA \\
DDE16S-UP & CGTGGGTAGCAAACAGGATT \\
DDE16S-DOWN & CCGGATGTCAAGCCTAGGTA & RTA \\
\hline
\end{tabular}

the manufacturer's instructions. A total of approximately 1 nmol of protein was used.

Two primers were designed according to $D$. desulfuricans G20 ZraP encoding gene (Table 1). Direct PCR of boiled cell suspensions allowed rapid amplification of the DNA fragment codifying MorP. Briefly, a $1 \mathrm{~mL}$ aliquot of $D$. alaskensis cells was washed and resuspended in $50 \mu \mathrm{L}$ of TE buffer (Tris-HCl 10 mM, 1 mM EDTA, pH 7.6). Then, the cell suspension was kept in a boiling water bath for 5 min, followed by centrifugation at $10000 \mathrm{rpm}$ for $5 \mathrm{~min}$. Volumes of 1 and $2 \mu \mathrm{L}$ of supernatant were used as DNA template. High fidelity Taq (Expand High Fidelity PCR System from Roche) was used for the amplification reaction. The PCR program for DNA amplification was the following: 2 min denaturation at $94{ }^{\circ} \mathrm{C}$, and 30 cycles of $30 \mathrm{~s}$ at $94{ }^{\circ} \mathrm{C}$, followed by $1 \mathrm{~min}$ at $66^{\circ} \mathrm{C}$ and $1 \mathrm{~min} 30 \mathrm{~s}$ at $72{ }^{\circ} \mathrm{C}$ for DNA extension. After these cycles the mixture was incubated for $7 \mathrm{~min}$ at $72{ }^{\circ} \mathrm{C}$, and cooled down to $4{ }^{\circ} \mathrm{C}$. The temperature of the lid was $105^{\circ} \mathrm{C}$. A fragment of approximately $1 \mathrm{kbp}$ was obtained and purified using QIAquick extraction kit (Qiagen). The DNA fragments were directly sequenced using an ABI3700 DNA analyzer (Perkin-Elmer/Applied Biosystems, Stabvida, Oerias, Portugal).

BLASTp (22) was used for sequence database searching, and CLUSTAL-W (23) was used to generate multiple sequence alignments. PromScan (http://www.promscan.uklinux.net) was used to scan DNA sequences for potential $\sigma^{54}$ RNA polymerase binding sites (24).

7. Quantitative Real Time PCR. D. desulfuricans G20 was grown in medium $\mathrm{C}$ (18) supplemented or not with $6.5 \mu \mathrm{M}$ ammonium molybdate $\left(\left(\mathrm{Mo}_{7}\right)\left(\mathrm{NH}_{4}\right)_{6} \mathrm{O}_{24} \cdot 4 \mathrm{H}_{2} \mathrm{O}\right)$ in an anaerobic COY chamber (gas atmosphere $\mathrm{H}_{2} 10 \%, \mathrm{~N}_{2} 90 \%$ ) at $32{ }^{\circ} \mathrm{C}$. After $12 \mathrm{~h}$ of culture, $25 \mathrm{~mL}$ total volume, from three independent cultures, was centrifuged at $4{ }^{\circ} \mathrm{C}$ for $20 \mathrm{~min}$ at $5500 \mathrm{~g}$ and the pellet was used for RNA preparation. The same procedure was done for cultures grown with $45 \mu \mathrm{M}$ copper sulfate.

Total RNAs were isolated using High Pure RNA kit from Roche. RNA quality was checked by electrophoresis on agarose gel and the absence of DNA contamination was confirmed by PCR. RNA quantification was performed spectrophotometrically. cDNA synthesis was performed as follows. $10 \mu \mathrm{M}$ total RNA and $3 \mu \mathrm{g}$ of random primers (Invitrogen) were first mixed, heated at $70{ }^{\circ} \mathrm{C}$ for $3 \mathrm{~min}$ and placed on ice until the addition of the cDNA synthesis mix (50 mM Tris- $\mathrm{HCl} \mathrm{pH} 8.3,40 \mathrm{mM} \mathrm{KCl}, 6 \mathrm{mM} \mathrm{MgCl}, 10$ mM DTT, $0.3 \mathrm{mM}$ dNTPs). The reaction mix $(30 \mu \mathrm{L})$ was incubated for $5 \mathrm{~min}$ at $25^{\circ} \mathrm{C}$ prior to the addition of 300 units of Superscript II Reverse transcriptase (Invitrogen). The mix was first incubated for $5 \mathrm{~min}$ at $25^{\circ} \mathrm{C}$ followed by $1 \mathrm{~h}$ incubation at $42{ }^{\circ} \mathrm{C}$. The reaction was stopped by heat inactivation (15 $\mathrm{min}$ at $\left.70{ }^{\circ} \mathrm{C}\right)$. Afterward, cDNA was purified by filtration on Microcon YM-30 (Millipore) and resuspended in $100 \mu \mathrm{L}$ of ultrapure water. cDNA was further used for either PCR or quantitative real-time PCR (qRTPCR).

Amplification and quantification of the cDNAs were performed with the LightCycler Real-Time PCR System (Roche) (a thermal cycler platform with fluorescence detection system for gene quantification) using the LightCycler FastStart DNA master ${ }^{\text {plus }}$ SYBR greenI kit (Roche), according to the manufacturer instructions. Primers were designed to specifically amplify a portion of each targeted gene. Primers sequences are described in table 1. All amplifications were performed in triplicates using $0.5 \mu \mathrm{L}$ of cDNA in each reaction. The LightCycler was programmed for an initial step at $95^{\circ} \mathrm{C}$ for $8 \mathrm{~min}$, followed by 45 thermal cycles at $95^{\circ} \mathrm{C}$ for $15 \mathrm{~s}, 55^{\circ} \mathrm{C}$ for $15 \mathrm{~s}$ and $72{ }^{\circ} \mathrm{C}$ for $20 \mathrm{~s}$. The specificities of accumulated products were verified by melting-curve analysis. Relative Expression Solftware Tool (REST) was used to calculate the relative expression of each gene in each condition (25), using the 16S RNA gene as reference for normalization.

8. XAS Data Collection and Analysis. Purified samples of MorP in Tris-HCl $100 \mathrm{mM}$ buffer ( $\mathrm{pH}$ 7.6) were transferred to Lucite sample cuvettes and frozen in liquid nitrogen. XAS measurements were carried out at the Stanford Synchrotron Radiation Laboratory (SSRL Stanford, CA) on beamline 9-3 using a $\mathrm{Si}(220)$ double crystal monochromator and Rh-coated silicon mirrors for focusing and harmonic rejection, with the storage ring SPEAR containing 90-100 $\mathrm{mA}$ at $3.0 \mathrm{GeV}$. The incident and transmitted X-ray intensities were measured using nitrogen- (Fe K-edge XAS) or argon-filled ionization chambers (Mo K-edge XAS). During data collection, the sample was maintained at $10 \mathrm{~K}$ using an Oxford Instruments liquid helium flow cryostat. The X-ray absorption spectra were measured as the $\mathrm{Fe} \mathrm{K} \alpha$ or $\mathrm{Mo} \mathrm{K} \alpha$ $\mathrm{X}$-ray fluorescence excitation spectra using a 30-element Ge detector (Canberra Ind.). The spectrum of iron or molybdenum metal foil was recorded simultaneously with each scan. Energy calibration was by reference to the lowest energy Fe K- or Mo K-edge inflection point of the standard foil, which was assumed to be 7111.3 and $20003.9 \mathrm{eV}$, respectively. The extended X-ray absorption fine structure (EXAFS) data were quantitatively analyzed by curve fitting using the EXAFSPAK suite of computer programs (http://ssrl.slac.stanford.edu/exafspak.html). Ab initio theoretical extended phase and amplitude fractions were calculated using FEFF, version 8.25 (26).

9. Density Functional Theory Geometry Optimization of Mo-2S-[2Fe-2S]-2S-Mo Cluster. Geometry optimization of the cluster was performed at the spin unrestricted generalized gradient approximation level (GGA) with the Becke-Perdew (BP) functional (27) of density functional theory (DFT) using 


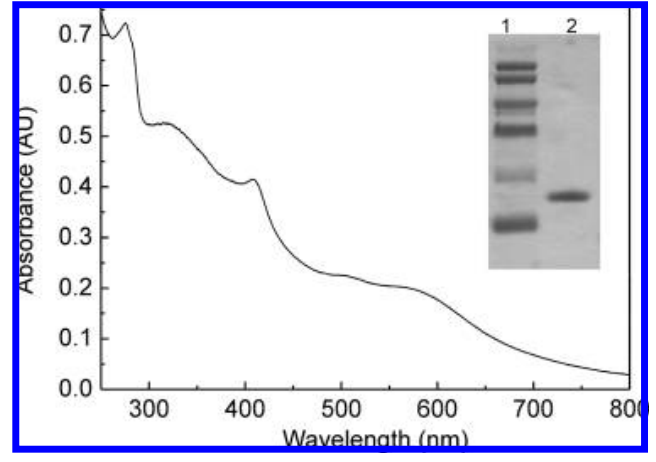

FIGURE 1: Ultraviolet-visible spectrum of MorP. Inset: 15\% trycine SDS-PAGE of MorP, lane 1, molecular mass standards (97, 66, 45, 30, 20.1, and 14.4 kDa); lane 2, MorP.

Accelrys Materials Studio V4.1 and $\mathrm{DMol}^{3}$. For all atoms double numerical plus d-functions basis sets (DND) and real space cutoff of $4.4 \AA$, and all-electron relativistic core potentials were used. No symmetry constraints were applied. $\mathrm{Fe}(\mathrm{II})$ and $\mathrm{Mo}(\mathrm{VI})$ oxidation states were assumed, resulting in an overall charge for the cluster of -4 . The effects of water solvation were simulated by using the conductor-like screening model (28).

\section{RESULTS}

1. A Novel Mo-Fe Protein Is Produced by D. alaskensis When Cells Are Grown in Medium Supplemented with Mo. A few proteins have been isolated and characterized from D. alaskensis cultured in medium C. Among these proteins are aldehyde oxide reductase and the $\mathrm{W}$ - and Mo-formate dehydrogenases which were isolated from the cells grown in lactate-sulfate medium $(20,29)$. Quantification of $\mathrm{Cu}, \mathrm{Fe}$, Mo and $\mathrm{W}$ in medium $\mathrm{C}$ showed that these metals, with exception of $\mathrm{Fe}$, are present in trace amounts (data not shown). Growing D. alaskensis in medium supplemented with Mo induced a visible change in the electrophoretic pattern of the soluble extract denoted by the large abundance of a new protein of approximately $15 \mathrm{kDa}$. Because the production of this protein was largely increased in the presence of Mo we refer to it as "molybdenum response associated protein" or MorP. In order to isolate MorP for further biochemical characterization, a two step purification protocol was performed. The protein did not bind to the first anionic exchange column, which is in agreement with the isoelectric point ( $\mathrm{p} I$ 9.24) predicted from amino acid sequence. The UV-visible spectrum of MorP-containing fraction revealed the presence of heme-containing proteins as contaminants which were separated using a HTP column. Although after this step the protein was in a high purity grade as judged by electrophoresis (inset in Figure 1), the UV-visible spectrum of MorP showed a minor band at 409 $\mathrm{nm}$ corresponding to a hemic protein (less than $10 \%$ of the total protein). In order to obtain a higher purity grade of MorP, several tests were performed. Size-exclusion gel chromatography was tested using either different ionic strengths $(50 \mathrm{mM}$ sodium phosphate and $50-450 \mathrm{mM} \mathrm{NaCl})$ or pHs (range from 6 to 9). Ionic exchange chromatography (MonoQ and Resource Q, GE Healthcare) were also tested without success. This purification protocol yielded about 1.7 $\mathrm{mg}$ of pure protein/L of cell culture. The UV-visible absorption spectrum of the as-isolated MorP shows absorp-

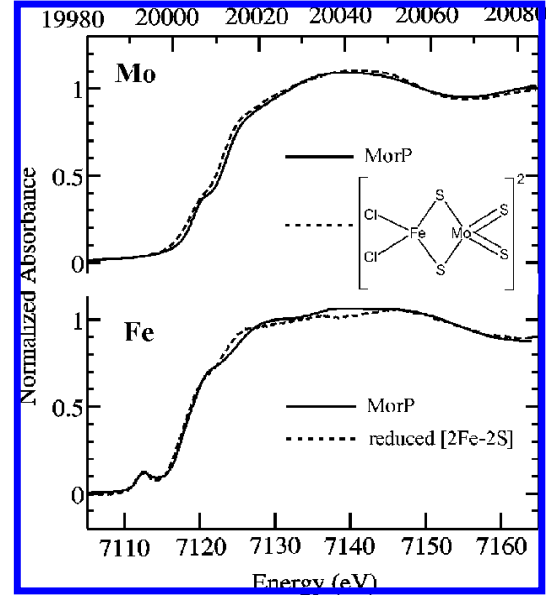

FIGURE 2: Normalized Mo and Fe near-edge spectra of MorP (solid lines) compared with the Mo and Fe K spectra of model complexes (broken lines).

tion bands around 280, 320, 409 and $570 \mathrm{~nm}$ (Figure 1) with an $A_{280} / A_{570}$ ratio of 3.5. The extinction coefficients for the pure protein in Tris- $\mathrm{HCl} 50 \mathrm{mM}$ buffer $\left(\mathrm{pH}\right.$ 7.6) are $\varepsilon_{280}=$ $18700, \varepsilon_{320}=12800$, and $\varepsilon_{570}=5000 \mathrm{M}^{-1} \mathrm{~cm}^{-1}$. Metal analysis by inductive coupled plasma emission revealed that MorP is a Mo-Fe containing protein with $1.2 \pm 0.2 \mathrm{Mo}$ and $1.2 \pm 0.3 \mathrm{Fe}$ per monomer. Quantification of labile sulfide yielded $3.9 \pm 0.6$ sulfur atoms per monomer.

2. MorP Is Purified as a Homomultimer Complex of High Molecular Weight. The MALDI-TOF mass spectrum of MorP showed a unique peak corresponding to a molecular mass of $15321.1 \pm 0.5 \mathrm{Da}$. The molecular weight of the as-purified protein obtained by gel filtration chromatography is $260 \pm 13 \mathrm{kDa}$ indicating that MorP is a homomultimer constituted by $16-18$ identical subunits.

3. MorP Contains a Mo-2S-[2Fe-2S]-2S-Mo Cluster. Figure 2 shows the molybdenum $\mathrm{K}$ near-edge spectrum of MorP. The near-edge spectra are sensitive to electronic structure of the metal center. The overall shape of the MorP spectrum resembles that of $\left[\mathrm{S}_{2} \mathrm{MoFeS}_{2} \mathrm{Cl}_{2}\right]^{2-}$ indicating some structural similarities between those two Mo centers (Figure 2). Both Mo near-edge spectra have a pre-edge feature at about $20008 \mathrm{eV}$, which is however more pronounced for the MorP spectrum. This so-called oxo-edge feature is characteristic of a species possessing $\mathrm{Mo}=\mathrm{O}$ groups (or to a lesser extent $\mathrm{Mo}=\mathrm{S}$ ) and is attributed to a Mo $1 \mathrm{~s} \rightarrow \mathrm{Mo}=\mathrm{O} \pi^{*}$ transition $(26,30,31)$. The intensity of the oxo-edge feature is also related to the number of $\mathrm{Mo}=\mathrm{O}$ ligands (32). Thus, the observed difference in the "oxo-edge" feature intensity argues for the presence of a $\mathrm{Mo}=\mathrm{O}$ ligand in MorP. In addition, the edge position of the MorP spectrum overlaps with that of $\left[\mathrm{S}_{2} \mathrm{MoFeS}_{2} \mathrm{Cl}_{2}\right]^{2-}$ indicating a formal metal oxidation state of $\mathrm{Mo}(\mathrm{VI})$ in the protein.

Conversely, the Fe K near-edge spectrum of MorP shows a different shape from that of $\left[\mathrm{S}_{2} \mathrm{MoFeS}_{2} \mathrm{Cl}_{2}\right]^{2-}$ (not illustrated) but instead resembles the spectrum of reduced [2Fe-2S] cluster in Anabaena ferredoxin (33-36) (Figure 2). Moreover, the MorP near-edge spectrum has a $1 \mathrm{~s} \rightarrow 3 \mathrm{~d}$ transition at $7112.4 \mathrm{eV}$, with similar position and intensity to that of the $[2 \mathrm{Fe}-2 \mathrm{~S}]$ cluster at $7112.5 \mathrm{eV}$ (we estimate the error in determining peak positions to be $\sim 0.1 \mathrm{eV}$ ). This pre-edge feature is sensitive to the electronic structure of the iron, and may be used as an indicator of metal ion 


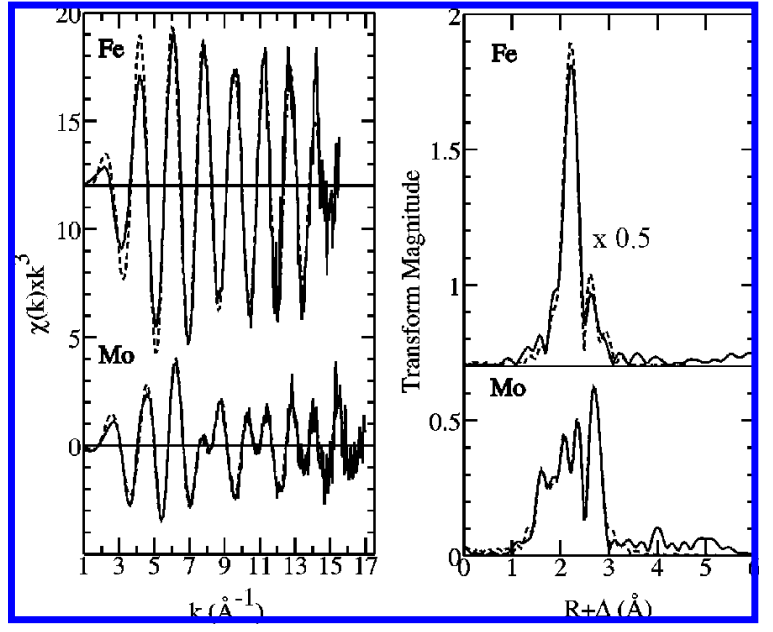

FIGURE 3: Mo and Fe K-edge $k^{3}$-weighted EXAFS spectra (left) and their Fourier transforms (right) of MorP. Experimental data are shown by solid lines; calculated spectra based on the models in Table 2 are represented by dashed lines.

Table 2: EXAFS Refinement Parameters for the Fe and Mo Site in MorP from D. alaskensis Compared with DFT-Optimized Bond Lengths $\left(R_{\mathrm{DFT}}\right)^{a}$

\begin{tabular}{clllll}
\hline$N$ & $\mathrm{C} \cdots \mathrm{L}$ & $R(\AA)$ & $\sigma^{2}\left(\AA^{2}\right)$ & $F$ & $R_{\mathrm{DFT}}(\AA)$ \\
\hline $\mathrm{Fe} \mathrm{K}$ & & & & & \\
4 & $\mathrm{Fe}-\mathrm{S}$ & $2.245(2)$ & $0.0035(1)$ & 0.263 & $2.25^{b}$ \\
1 & $\mathrm{Fe}-\mathrm{Mo}$ & $2.72(1)$ & $0.0028(5)$ & & 2.79 \\
1 & $\mathrm{Fe}-\mathrm{Fe}$ & $2.70(1)$ & $0.0012(6)$ & & 2.65 \\
$\mathrm{Mo} \mathrm{K}$ & & & & & \\
0.6 & $\mathrm{Mo}=\mathrm{O}$ & $1.678(2)$ & $0.0012(2)$ & 0.324 & $1.76^{c}$ \\
0.4 & $\mathrm{Mo}-\mathrm{O}$ & $2.02(3)$ & $0.006(3)$ & & \\
1 & $\mathrm{Mo}=\mathrm{S}$ & $2.188(7)$ & $0.0050(6)$ & & 2.23 \\
2 & $\mathrm{Mo}-\mathrm{S}$ & $2.347(4)$ & $0.0060(3)$ & & 2.29 \\
1 & $\mathrm{Mo}-\mathrm{Fe}$ & $2.713(2)$ & $0.0029(1)$ & & 2.79 \\
\hline
\end{tabular}

${ }^{a}$ The numbers $(N)$ of ligand atoms $(\mathrm{L})$, their distance to the central ion $(\mathrm{C})$, the respective Debye-Waller factor $\left(2 \sigma^{2}\right)$ and the fit-error function value $(F)$, indicating the quality of the fit, are shown. Values in parentheses represent estimated standard deviations obtained from the diagonal elements of the covariance matrix. ${ }^{b}$ Value averaged over eight different $\mathrm{Fe}-\mathrm{S}$ bond lengths. ${ }^{c}$ Single $\mathrm{Mo}=\mathrm{O}$ was assumed.

coordination number (37). Furthermore, the $\mathrm{Fe}$ K-edge position of MorP is closer to that of reduced than of oxidized [2Fe-2S] cluster (not illustrated). Overall, the near-edge comparison indicates that the iron has similar local environment to that of $[2 \mathrm{Fe}-2 \mathrm{~S}]$ cluster and that its average iron oxidation state is probably lower than +3 .

The Mo and Fe K-edge EXAFS spectra provide further insights into the metal ion coordination in MorP. Figure 3 shows the Fe and Mo K-edge $k^{3}$-weighted EXAFS spectra, together with their respective best fits and corresponding Fourier transforms. The results of the EXAFS curve-fitting analysis are presented in Table 2. The Mo K-edge EXAFS Fourier transform suggests that the EXAFS comprises five major interactions, giving rise to the transform peaks at $R$ $+\Delta \approx 1.6,1.9,2.1,2.4$ and $2.7 \AA$. For the quantitative EXAFS analysis several different coordination models were considered for their consistency with the data and the following single interactions could be identified: $\mathrm{Mo}=\mathrm{O}$ at $1.68 \AA, \mathrm{Mo}-\mathrm{O} / \mathrm{N}$ at $2.02 \AA, \mathrm{Mo}=\mathrm{S}$ at $2.19 \AA, \mathrm{Mo}-\mathrm{S}$ at $2.35 \AA$ and $\mathrm{Mo}-\mathrm{Fe}$ at $2.71 \AA$. The $\mathrm{Mo}=\mathrm{O}$ in MorP is in excellent agreement with the values reported for $\mathrm{Mo}(\mathrm{VI})$ mono oxo complexes (38). A short $\mathrm{Mo}=\mathrm{S}$ bond length is consistent with bond lengths derived from EXAFS of model complexes with [Mo(VI)OS] moiety (39). The slightly increased Debye - Waller factor of the single oxo contribution $\left(\sigma^{2}=0.0032 \AA^{2}\right)$ together with highly elevated Debye-Waller factor of the single $\mathrm{Mo}-\mathrm{O}$ bond $\left(\sigma^{2}=0.013 \AA^{2}\right)$ suggested the occupancy of both ligands to be lower than one. To estimate the occupancy of the $\mathrm{Mo}=\mathrm{O}$ and $\mathrm{Mo}-\mathrm{O}$ in the sample, their partial coordination numbers were varied but their sum was kept as 1 . The overall best fit was obtained with $60 \%$ occupancy for the $\mathrm{Mo}=\mathrm{O}$ bond and $40 \%$ for the Mo-O. Thus, the final structural model of the Mo site in MorP consists of $0.6 \mathrm{O}$ at $1.68 \AA, 0.4 \mathrm{O}$ at $2.02 \AA, 1 \mathrm{~S}$ at $2.19 \AA, 2 \mathrm{~S}$ at $2.35 \AA$ and $1 \mathrm{Fe}$ at $2.71 \AA$ (Table 2). The Mo-O bond length of $2.02 \AA$ may be assigned to either a hydroxyl or carboxylate ligand. Thus, the reasons for the partial occupancy of the oxygen ligand in MorP may be 2 -fold. One could be a partial reduction of the MorP sample, i.e. conversion of the double-bonded oxo group to a hydroxyl ligand. Another possible explanation could be a presence of two different Mo sites in MorP, one with single oxo ligand and one with oxygen atom provided by an amino acid.

The Fourier transform of the $\mathrm{Fe} \mathrm{K}$-edge $k^{3}$-weighted EXAFS data exhibits only two main peaks at $\sim 2.2 \AA$ and at $\sim 2.6 \AA$ (Figure 3). The first peak corresponds to iron-first shell ligand backscattering contributions, which was best modeled as four $\mathrm{Fe}-\mathrm{S}$ interactions at $2.24 \AA$ (Table 2). This bond length is very similar to that found for $[2 \mathrm{Fe}-2 \mathrm{~S}]$ in small molecules in the Cambridge Structure database which give an overall average $\mathrm{Fe}-\mathrm{S}$ bond length of $2.25 \AA$ (40). Fe based on the Mo K-edge EXAFS analysis the second peak could be attributed to the $\mathrm{Fe}-\mathrm{Mo}$ contribution. However, the EXAFS curve fitting using such a model resulted in significantly longer $\mathrm{Fe}$-Mo distances than that obtained from the Mo K-edge EXAFS (2.79 $\AA$ vs $2.71 \AA$ ). Furthermore, the corresponding Debye - Waller factors were substantially mismatched (0.006 $\AA^{2}$ vs $0.003 \AA^{2}$ ). These results prompted us to examine the possible presence of an additional metal-metal contribution at similar distance, which could potentially interfere destructively with the $\mathrm{Fe}-\mathrm{Mo}$ signal. Similar EXAFS cancellation phenomena have previously been observed in a number of systems, for example cuprousthiolate clusters (41). Here, the EXAFS from two components are close to $180^{\circ}$ out of phase with each other and the EXAFS of these components wholly or partially cancel resulting in diminished amplitude. The presence of the $\mathrm{Fe}-\mathrm{Fe}$ bond concomitantly with the $\mathrm{Fe}-\mathrm{Mo}$ bond was tested, and its inclusion produced overall better fit (a reduction in the fit-error from 0.301 to 0.263 , with an estimated contribution from noise in the data to the fit-error of $\sim 0.22$ ). Furthermore, the refined $\mathrm{Fe}-\mathrm{Mo}$ distance was quite consistent with Mo K-edge EXAFS (Table 2). We note that some caution is always appropriate when investigating EXAFS cancelation (even if only a partial cancelation in this case). Thus, the parameters for the $\mathrm{Fe}-\mathrm{Mo}$ and $\mathrm{Fe}-\mathrm{Fe}$ are highly correlated in the refinement, and examination of the covariance matrix indicates that the two Debye-Waller factors are $\sim 80 \%$ correlated, indicating that these values should be considered approximate, and this is reflected in the estimated standard deviations given in Table 2. In summary, the XAS results suggest a $[2 \mathrm{Fe}-2 \mathrm{~S}]$ cluster bridged to the Mo ion through two sulfur atoms.

Together, the XAS analysis and the Mo:Fe ratio of 1 per MorP monomer indicate that MorP is constituted by homodimers containing a Mo-2S-[2Fe-2S]-2S-Mo cluster, with 


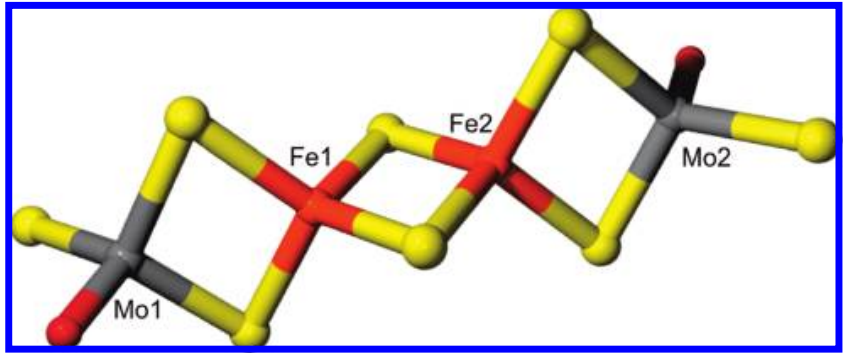

FIGURE 4: DFT geometry-optimized structure of Mo-2S-[2Fe-2S]$2 \mathrm{~S}-\mathrm{Mo}$ cluster. In the figure, unlabeled atoms are oxygen (red) and carbon (dark gray).

the presence of a lower nuclearity cluster being excluded by the presence of Fe-Fe EXAFS. Either this cluster bridges between the two monomers, or the protein is approximately half-occupied, with the remainder being apoprotein.

The search for tetranuclear cluster in the Cambridge Structural Database, similar to the one proposed here, revealed a nearly linear $\left[\left(\mathrm{MoO}_{2} \mathrm{~S}_{2}\right)_{2} \mathrm{Fe}_{2} \mathrm{~S}_{2}\right]^{4-}$ cluster, formally containing $\mathrm{Mo}(\mathrm{VI})$ and $\mathrm{Fe}(\mathrm{II})$, with all metal atoms having an approximately tetrahedral coordination geometry consisting of bridging sulfides and/or terminal oxygen atoms (42). This species has terminal four $\mathrm{Mo}=\mathrm{O}$ groups (two per Mo) as the external ligands to Mo, and differs from the model suggested by the EXAFS in having a more $\mathrm{Mo}=\mathrm{O}$ coordination. The crystallographic coordinates of $\left[\left(\mathrm{MoO}_{2} \mathrm{~S}_{2}\right)_{2} \mathrm{Fe}_{2} \mathrm{~S}_{2}\right]^{4-}$ were used to build a possible model of the MorP cluster (Figure 4). It was assumed that the MorP cluster is not covalently tethered to the protein by an amino acid chain, e.g. all bridging sulfurs are sulfides and both Mo sites are identical and each has a single oxo ligand. Accordingly, one of the two terminal oxygen atoms at each Mo site in $\left[\left(\mathrm{MoO}_{2} \mathrm{~S}_{2}\right)_{2} \mathrm{Fe}_{2} \mathrm{~S}_{2}\right]^{4-}$ was replaced with sulfur atom and the $\mathrm{Mo}=\mathrm{O}$ and $\mathrm{Mo}=\mathrm{S}$ bond lengths were adjusted to the values obtained from the EXAFS analysis to form $\left[\left(\mathrm{MoOS}_{3}\right)_{2}-\right.$ $\left.\mathrm{Fe}_{2} \mathrm{~S}_{2}\right]^{4-}$. To verify the stability of this newly constructed cluster we optimized its geometry using density functional theory (DFT) energy minimization. During the optimization process it was assumed that the overall charge of the cluster is -4 due to the oxidation state of $\mathrm{Mo}(\mathrm{VI})$ and $\mathrm{Fe}(\mathrm{II})$, consistent with the XAS results. The DFT calculations converged readily, indicating that the proposed cluster is chemically reasonable, and selected bond lengths from the energy-minimized structure are given in Table 2. Alternative models were also tested using DFT, in particular employing bridging thiolates in place of the bridging sulfides between the two Fe atoms (not illustrated). In this case, DFT of a putative $\left[\left(\mathrm{MoOS}_{3}\right)_{2} \mathrm{Fe}_{2}(\mathrm{~S}-\mathrm{Cys})_{2}\right]^{2-}$ cluster gave somewhat longer $\mathrm{Fe}-\mathrm{S}(\mathrm{Cys})$ bond lengths (increased by $\sim 0.1 \AA$ ). [2Fe2(SR)] clusters from the Cambridge crystal structure database indicate similar $\mathrm{Fe}-\mathrm{SR}$ bond lengths. Such bond lengths would not readily be resolved from the other $\mathrm{Fe}-\mathrm{S}$ distances by our EXAFS data, and would yield an overall longer average $\mathrm{Fe}-\mathrm{S}$ bond length. However, the close correspondence with the expected $\mathrm{Fe}-\mathrm{S}$ bond lengths argues against bridging thiolate coordination in the protein-bound cluster.

EPR spectra recorded for the isolated MorP samples shows a nearly isotropic signal $(g=2.012)$ accounting for less than 0.1 spins per protein (Supporting Information, Figure 2) and most of the protein is in an EPR silent state. This indicates that the metal cluster is diamagnetic or an integer spin system. Upon reduction with sodium dithionite the isotropic signal disappears and a completely EPR silent spectra is obtained. No changes in the spectra are observed when the sample is oxidized with ferrycyanide.

Table 2 shows the DFT-optimized bond lengths of the cluster. In general, the DFT computed distances agree reasonably well with those determined by EXAFS. For the $\mathrm{Mo}=\mathrm{O}$ and $\mathrm{Mo}-\mathrm{Fe}$ bonds slightly longer distances were obtained (by $\sim 0.08 \AA$ ). This, however, is not unexpected because of the well-known tendency of density functional methods to overestimate bond lengths, especially in the presence of the second-row elements such as Mo (43).

Similarly to the $\left[\left(\mathrm{MoO}_{2} \mathrm{~S}_{2}\right)_{2} \mathrm{Fe}_{2} \mathrm{~S}_{2}\right]^{4-}$ cluster, the DFT optimized structure revealed an almost linear arrangement of $\mathrm{Fe}$ and Mo atoms (with $\mathrm{Mo} \cdots \mathrm{Fe} \cdots \mathrm{Fe}$ angle of $177^{\circ}$ ). Consequently, the long distance EXAFS contribution would be expected, giving rise to a small peak in the Mo and $\mathrm{Fe}$ EXAFS Fourier transform at about 5.4 A. However, no such feature is observed (Figure 3) indicating the distortion of the linear arrangement of $\mathrm{Mo}$ and $\mathrm{Fe}$ atoms in MorP.

4. Analysis of the MorP Sequence Shows Homology with Zinc Resistance Associated Proteins from Desulfovibrio Genus. A BlastP search revealed that the N-terminal amino acid sequence of purified MorP from D. alaskensis (GPYGH GYGHR GGYGG MGSGG GAAVC PFGGS GPGGQ AA) shows $97.3 \%$ of identity with a putative zinc resistanceassociated protein deduced from D. desulfuricans G20 genome (www.tigr.org). This high sequence homology is due to the fact that $D$. alaskensis and $D$. desulfuricans G20 may be subspecies or the same species $(44,45)$ but different strains. Owing to this, the DNA fragment containing the open reading frame codifying MorP was amplified using primers designed from the available $D$. desulfuricans G20 DNA sequence. The DNA fragment obtained (1102 bp) shows $99.4 \%$ of identity with the corresponding genes from $D$. desulfuricans G20. Analysis of the DNA sequence shows a putative ribosomal binding site (RBS) motif, AAGG, located $20 \mathrm{bp}$ upstream of the ATG codon and a putative $\sigma^{54}$ promoter (ATGGCACGCCTGTTGCT) with a 98 score. A blast search of the deduced amino acid sequence of MorP shows $40 \%$ of identity with a putative ZraP present in $D$. vulgaris Hildenborough genome (Figure 5). The analysis of the deduced amino acid sequence of MorP shows that the protein is constituted by 172 residues with the first 24 amino acids corresponding to a periplasmic signal peptide. In agreement with the mass spectrometry results, the molecular weight calculated for the mature protein was 15321.25 Da.

The analysis of $D$. desulfuricans G20 genome shows that a two component system is located upstream of ZraP (Dde_0111). In these systems the first component functions as a sensor (Dde_0110) and the second is a response regulator (Dde_0109). This gene cluster was also observed in the upstream region of the homologous gene (DVU3384) in $D$. vulgaris Hildenborough (Figure 6).

5. MorP Expression Is Induced by Molybdenum. The production of MorP by $D$. alaskensis cells grown in medium C supplemented with $45 \mu \mathrm{M}$ of copper, iron, molybdenum, tungsten or zinc was tested. Besides Mo, only $\mathrm{Cu}$ seems to induce the expression of MorP. Band intensities measurements show an increase of 1.6 times in the presence of $\mathrm{Cu}$ and 2.4 times for Mo compared to the band intensity without metal addition (Figure 7). 


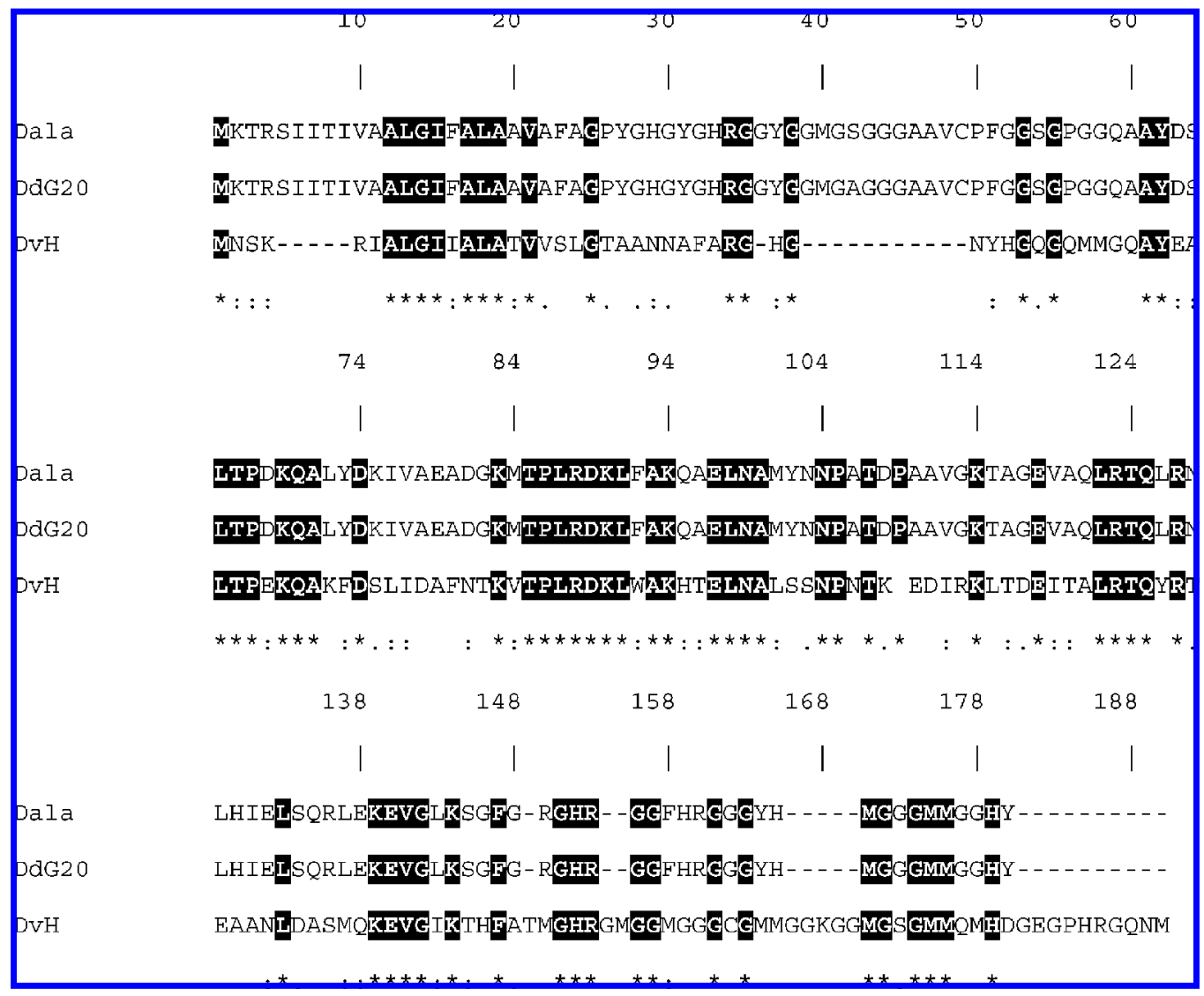

FIGURE 5: Multiple sequence alignment between MorP, and zinc resistance associated proteins translated from Desulfovibrio desulfuricans G20 and Desulfovibrio vulgaris Hildenborough genomes, respectively. (*) Identity, (:) strongly similar, and (.) weakly similar.

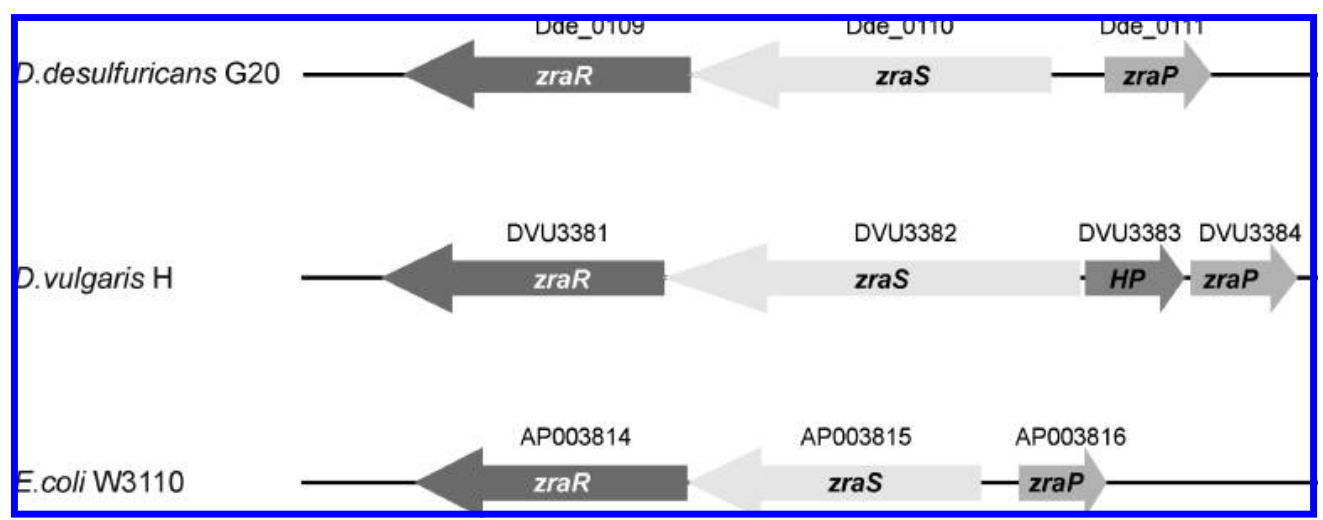

FIGURE 6: Organization of the two component system located upstream of the zraP gene in D. desulfuricans G20, D. vulgaris Hildenborough, and E. coli W3110.

In order to determine the Mo concentration that induces a significant increase in the protein production of MorP, the electrophoretic pattern of the periplasmic fraction of cells grown in a medium supplemented with different molybdate concentrations was analyzed. Figure 8 shows an intense band corresponding to MorP when cells were grown with more than $5 \mu \mathrm{M}$ molybdate.

To confirm the increase in expression at a transcriptional level qRT-PCR was performed on D. desulfuricans G20 grown in medium $\mathrm{C}$ supplemented with either $45 \mu \mathrm{M}$ molybdenum or copper. The results show that the expression of the gene coding for MorP is strongly induced (168-fold) by the presence of molybdenum. The MorP expression was also up-regulated by copper but at a much lower extent (5 times). Since the gene coding for MorP could be regulated by a two component system similar to that of the ZraP in $E$. coli (46), we looked at the expression of the putative regulator. As for morP gene, Dde_O109 was up-regulated (34 times) when cells were cultured in the presence of Mo.

\section{DISCUSSION}

D. alaskensis cells grown in lactate/sulfate medium in the presence of molybdate produce high levels of a novel metalloprotein (MorP) containing a heterometallic $2 \mathrm{Mo}-2 \mathrm{Fe}$ cluster not reported before.

MorP contains approximately 1 Mo per monomer yielding 16-18 molybdenum atoms per protein. Proteins able to bind multiple Mo atoms were reported to be involved in Mo transport, intracellular transfer, gene regulation, and homeostasis. The Mop from Haemophilus influenzae (47), Sporomusa ovata (48), and ModG from Azotobacter vinelandii $(49,50)$ 


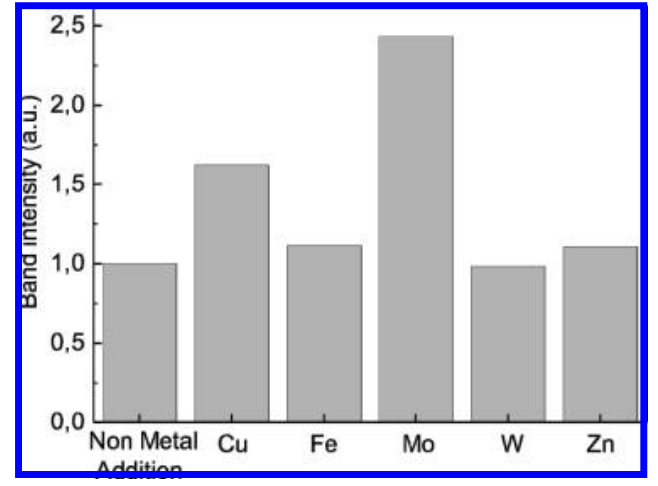

FIGURE 7: Densitometric analysis of MorP band of the same amount of total proteins applied on SDS-PAGE from $D$. alaskensis growths in $\mathrm{C}$ medium supplemented with different metals $(\mathrm{Cu}, \mathrm{Fe}, \mathrm{Mo}, \mathrm{W}$ and $\mathrm{Zn}$ ). Gels were stained by coomassie blue, and the relative intensities of the MorP band were estimated using ImageMaster 2D Platinum software.

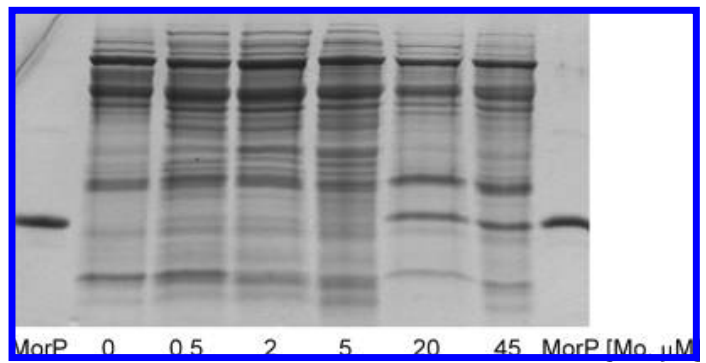

FIGURE 8: Mo-dependent production of MorP by D. alaskensis cells. SDS-PAGE analysis was performed on total proteins from cells grown under different molybdate concentrations. The MorP band was identified by in-gel digestion followed by MALDI-TOF-MS analysis.

belonging to the molbindin family of proteins, are wellknown systems able to bind up to 8 Mo atoms. These proteins contain a distinct molybdate binding domain of 69 amino acids which is a feature of the molbindin family (48). Although MorP appears to be involved in Mo homeostasis, its biochemical properties show that it is not included in the molbindin family. In fact, amino acid sequence analysis revealed neither the presence of the molbindin domain nor any conserved motifs known to bind metal ions.

Both EXAFS results and metal quantification data allowed us to propose the Mo-2S-[2Fe-2S]-2S-Mo cluster shown in Figure 4 . The cluster presents a $[2 \mathrm{Fe}-2 \mathrm{~S}]$ arrangement similar to that observed in Anabaena ferredoxin (33-36) but with each iron symmetrically bridged to 1 Mo atom by two inorganic sulfurs. The synthetic chemistry of $\mathrm{Mo}$ and $\mathrm{Fe}$ sulfide cluster has been well investigated. However, most of the reported species are high nuclearity Mo-Fe-S clusters $(51,52)$, which are of interest as potential synthetic precursors to the $\mathrm{MoFe}_{7} \mathrm{~S}_{9}$ cofactor cluster of nitrogenase (3-5). A "linear" tetranuclear cluster $\left[\left(\mathrm{MoO}_{2} \mathrm{~S}_{2}\right)_{2} \mathrm{Fe}_{2} \mathrm{~S}_{2}\right]^{4-}$ similar to the one contained in MorP was described in literature resulting from the anaerobic aqueous reaction of $\mathrm{Fe}^{2+}$ and $\mathrm{MoO}_{4-x} \mathrm{~S}_{x}{ }^{2-}(x=2-4)$ (42). The UV-visible spectrum of this synthetic cluster shows bands around 510, 350 and 290, which are similar to that obtained for MorP. The model constructed based on this cluster was in good agreement with the distances calculated by DFT suggesting that the two Fe atoms in the Mo-2S-[2Fe-2S]-2S-Mo cluster are likely bridged by two sulfides, and not by sulfurs from cysteine or methionine residues. Although the latter scenario cannot be completely ruled out based solely on the XAS analysis, it is important to note that there are no recognizable metal binding motifs in the amino acid sequence. The only cysteine residue (C49) present in MorP aminoacid sequence from D. alaskensis and D. desulfuricans $G 20$ (probably different strains from the same species) is not conserved in $D$. vulgaris Hildenborough (Figure 5). The conserved methionines at the C-terminal (M175, and M176) could be good candidates for cluster binding, however these residues are not conserved in homologous proteins isolated from D. gigas and $D$. aminophilus (Moura et al., unpublished results).

The analysis of the $D$. desulfuricans $\mathrm{G} 20$ and $D$. vulgaris Hildenborough genomes shows that MorP protein homologues are predicted as zinc resistance associated proteins (ZraP) regulated by a two component system called ZraRS (Figure 6). In E. coli, two component signal transduction is the primary signal transduction mechanism used to conduct global regulation of cells responses to changes in the environment. High concentrations of $\mathrm{Zn}^{2+}$ and $\mathrm{Pb}^{2+}$ specifically induce ZraP expression and also autogenously activate the $\mathrm{zraS} / \mathrm{R}$ expression $(46,53)$. The increase of morP gene expression by Mo supplementation and the analysis of the genes present in the surrounding area suggest that MorP is part of the same kind of metal resistance system but regulated by Mo. Accordingly, quantitative real time PCR experiments on $D$. desulfuricans $\mathrm{G} 20$ show that expression level of the putative regulator, $\operatorname{mor} R$, is also extremely increased by Mo induction (34-fold) supporting the idea that morP gene is regulated by the two component system located just upstream in the genome. Supplementation of the medium with $\mathrm{Cu}$ also increases morP expression but at much lower levels than Mo. The lower response to $\mathrm{Cu}$ could indicate less specificity of the sensor to this metal compared to Mo. Other reasons for this fact could be either the lower $\mathrm{Cu}$ ions availability (copper precipitates as copper sulfide) or the higher stress levels induced by copper when compared with the same molybdate concentrations for $D$. alaskensis species (revealed by growth inhibition (54)).

$E$. coli has at least three independent molybdate transport systems: a specific transport system coded by the mod gene cluster, the sulfate transport system, and a nonspecific transport system (13). The specific transport system coded by the $\bmod A B C$ operon is induced only under molybdate starvation and is repressed in presence of molybdate by the ModE-molybdate complex (12, 45-47). Several studies have shown that, at high molybdenum concentration, cells incorporate the metal by the other two machineries (13). Despite that several Mo-proteins have been characterized in sulfate reducing bacteria, there are no reports addressing Mo homeostasis. An analysis of the D. desulfuricans G20 genome shows that mod genes are also present in this organism (13) suggesting that cells incorporate Mo by similar transport systems. By analogy with E. coli, it can be supposed that despite that mod genes are repressed at high molybdenum concentration, the metal ions continue to enter cells by other systems. Therefore, MorP could be a periplasmic protein involved in Mo tolerance. However, the fact that a homologous protein in D. vulgaris Hildenborough (DVU3384) is up-regulated by oxidative stress (55) and that morP expression also responds to $\mathrm{Cu}$ in the culture medium could suggest that this two component system not only is involved in Mo tolerance but also can be activated by other changes 
in the environmental conditions. Nevertheless, a reasonable functional hypothesis for this system responding to increasing of Mo concentrations is the classical view of two component regulated systems. This hypothesis proposes that MorS (the histidine protein kinase) senses the increasing of Mo in the medium and undergoes autophosphorylation at a conserved His residue creating a highly reactive phosphoryl group that is transferred to a residue, probably a conserved Asp on MorR (the response regulator protein), which is a protein of the $\sigma 54$ type. A putative $\sigma 54$ promoter was identified in the upstream coding sequence of MorP, with a score higher than that for E. coli ZraP $\sigma 54$ promoter, 98 and 88.6, respectively (56). The regulator then activates the expression of the morP gene and MorP containing an identified signal peptide is driven from cytoplasm to periplasm where it can sequester Mo forming the Mo-Fe cluster described above.

In summary, in this work a new metalloprotein containing a novel Mo-Fe cluster that cannot be included in any of the families of molybdenum proteins described so far is presented. Moreover, the expression of the gene encoding MorP is significantly increased by Mo and is regulated by a two component system. Further studies are necessary to confirm the role of this protein in cell metabolism and the specificity of the response to changes in environmental conditions.

\section{ACKNOWLEDGMENT}

The authors thank Prof. J. L. Capelo-Martinez (Bioscope, Chemistry Department, FCT, UNL) for the MS analysis, Dr. Marta R. Santos (Chemistry Department, FCT, UNL) for N-terminal sequencing of MorP, and Carla Rodrigues (Chemistry Department, FCT, UNL) for inductively coupled plasma (ICP) analysis. We also thank Dr. Dimitri Coucouvanis (University of Michigan, Chemistry Department) for his generous gift of a sample of $\left[\mathrm{S}_{2} \mathrm{MoFeS}_{2} \mathrm{Cl}_{2}\right]\left[\mathrm{PPh}_{4}\right]_{2}$.

\section{SUPPORTING INFORMATION AVAILABLE}

The chromatogram of the size exclusion column as well as the EPR spectra of the native protein. This material is available free of charge via the Internet at http://pubs.acs.org.

\section{REFERENCES}

1. Mendel, R. R. (2005) Molybdenum: biological activity and metabolism. Dalton Trans. 3404-3409.

2. Moura, J. J., Brondino, C. D., Trincao, J., and Romao, M. J. (2004) Mo and W bis-MGD enzymes: nitrate reductases and formate dehydrogenases. J. Biol. Inorg. Chem. 9, 791-799.

3. Einsle, O., Tezcan, F. A., Andrade, S. L. A., Schmid, B., Yoshida, M., Howard, J. B., and Rees, D. C. (2002) Nitrogenase MoFeProtein at 1.16 A Resolution: A Central Ligand in the FeMoCofactor. Science 297, 1696-1700.

4. Chan, M. K., Kim, J., and Rees, D. C. (1993) The nitrogenase FeMo-cofactor and P-cluster pair: 2.2 A resolution structures. Science 260, 792-794.

5. Kim, J., and Rees, D. C. (1992) Structural models for the metal centers in the nitrogenase molybdenum-iron protein. Science 257, 1677-1682.

6. Bursakov, S. A., Gavel, O. Y., Di Rocco, G., Lampreia, J., Calvete, J., Pereira, A. S., Moura, J. J., and Moura, I. (2004) Antagonists $\mathrm{Mo}$ and $\mathrm{Cu}$ in a heterometallic cluster present on a novel protein (orange protein) isolated from Desulfovibrio gigas. J. Inorg. Biochem. 98, 833-840.

7. George, G. N., Pickering, I. J., Yu, E. Y., Prince, R. C., Bursakov, S. A., Gavel, O. Y., Moura, I., and Moura, J. J. G. (2000) A Novel Protein-Bound Copper-Molybdenum Cluster. J. Am. Chem. Soc. 122, 8321-8322.
8. Scholten, J. C., Culley, D. E., Brockman, F. J., Wu, G., and Zhang, W. (2007) Evolution of the syntrophic interaction between Desulfovibrio vulgaris and Methanosarcina barkeri: Involvement of an ancient horizontal gene transfer. Biochem. Biophys. Res. Commun. 352, 48-54.

9. Maupin-Furlow, J. A., Rosentel, J. K., Lee, J. H., Deppenmeier, U., Gunsalus, R. P., and Shanmugam, K. T. (1995) Genetic analysis of the modABCD (molybdate transport) operon of Escherichia coli. J. Bacteriol. 177, 4851-4856.

10. Rech, S., Deppenmeier, U., and Gunsalus, R. P. (1995) Regulation of the molybdate transport operon, modABCD, of Escherichia coli in response to molybdate availability. J. Bacteriol. 177, 1023-1029.

11. Rosentel, J. K., Healy, F., Maupin-Furlow, J. A., Lee, J. H., and Shanmugam, K. T. (1995) Molybdate and regulation of mod (molybdate transport), fdhF, and hyc (formate hydrogenlyase) operons in Escherichia coli. J. Bacteriol. 177, 4857-4864.

12. Grunden, A. M., Ray, R. M., Rosentel, J. K., Healy, F. G., and Shanmugam, K. T. (1996) Repression of the Escherichia coli modABCD (molybdate transport) operon by ModE. J. Bacteriol. 178, 735-744.

13. Grunden, A. M., and Shanmugam, K. T. (1997) Molybdate transport and regulation in bacteria. Arch. Microbiol. 168, 345-354.

14. Duhme, A. K., Meyer-Klaucke, W., White, D. J., Delarbre, L., Mitchenall, L. A., and Pau, R. N. (1999) Extended X-ray absorption fine structure studies on periplasmic and intracellular molybdenumbinding proteins. J. Biol. Inorg. Chem. 4, 588-592.

15. Fenske, D., Gnida, M., Schneider, K., Meyer-Klaucke, W., Schemberg, J., Henschel, V., Meyer, A. K., Knochel, A., and Muller, A. (2005) A new type of metalloprotein: The Mo storage protein from azotobacter vinelandii contains a polynuclear molybdenum-oxide cluster. ChemBioChem 6, 405-413.

16. Rodionov, D. A., Dubchak, I., Arkin, A., Alm, E., and Gelfand, M. S. (2004) Reconstruction of regulatory and metabolic pathways in metal-reducing delta-proteobacteria. Genome Biol. 5, R90.

17. Peck, H. D. (1959) The Atp-Dependent Reduction of Sulfate with Hydrogen in Extracts of Desulfovibrio desulfuricans. PNAS 45, 701-708.

18. Posgate, J. R. (1984) The sulphate-reducing bacteria, 2nd ed., Cambridge University Press, Cambridge.

19. Cordeiro, F. M., Carreira, R. J., Rial-Otero, R., Rivas, M. G., Moura, I., and Capelo, J. L. (2007) Simplifying sample handling for protein identification by peptide mass fingerprint using matrixassisted laser desorption/ionization time-of-flight mass spectrometry. Rapid Commun. Mass Spectrom. 21, 3269-3278.

20. Brondino, C. D., Passeggi, M. C., Caldeira, J., Almendra, M. J., Feio, M. J., Moura, J. J., and Moura, I. (2004) Incorporation of either molybdenum or tungsten into formate dehydrogenase from Desulfovibrio alaskensis NCIMB 13491; EPR assignment of the proximal iron-sulfur cluster to the pterin cofactor in formate dehydrogenases from sulfate-reducing bacteria. J. Biol. Inorg. Chem. 9, 145-151.

21. Fogo, J. K., and Popowsky, M. (1949) Spectrophotometric Determination of Hydrogen Sulfide. Anal. Chem. 21, 732-734.

22. Altschul, S. F., Gish, W., Miller, W., Myers, E. W., and Lipman, D. J. (1990) Basic local alignment search tool. J.Mol. Biol. 215, 403-410.

23. Thompson, J. D., Gibson, T. J., Plewniak, F., Jeanmougin, F., and Higgins, D. G. (1997) The CLUSTAL_X windows interface: flexible strategies for multiple sequence alignment aided by quality analysis tools. Nucleic Acids Res. 25, 4876-4882.

24. Studholme, D. J., Buck, M., and Nixon, T. (2000) Identification of potential \{sigma $\mathrm{N}$-dependent promoters in bacterial genomes. Microbiology 146, 3021-3023.

25. Pfaffl, M. W. (2001) A new mathematical model for relative quantification in real-time RT-PCR. Nucleic Acids Res. 29, e45.

26. Kutzler, F. W., Natoli, C. R., Misemer, D. K., Doniach, S., and Hodgson, K. O. (1980) Use of one-electron theory for the interpretation of near edge structure in K-shell x-ray absorption spectra of transition metal complexes. J. Chem. Phys. 73, 32743288.

27. Becke, A. D. (1988) A multicenter numerical integration scheme for polyatomic molecules. J. Chem. Phvs. 88, 2547-2553.

28. Delley, B. (2006) The conductor-like screening model for polymers and surfaces. Mol. Simul. 32, 117-123.

29. Andrade, S. L., Brondino, C. D., Feio, M. J., Moura, I., and Moura, J. J. (2000) Aldehyde oxidoreductase activity in Desulfovibrio alaskensis NCIMB 13491 EPR assignment of the proximal [2Fe2S] cluster to the Mo site. Eur. J. Biochem. 267, 2054-2061. 
30. George, G. N., Garrett, R. M., Prince, R. C., and Rajagopalan, K. V. (1996) The Molybdenum Site of Sulfite Oxidase: A Comparison of Wild-Type and the Cysteine 207 to Serine Mutant Using X-ray Absorption Spectroscopy. J. Am. Chem. Soc. 118, $8588-8592$.

31. George, G. N., Hilton, J., and Rajagopalan, K. V. (1996) X-ray Absorption Spectroscopy of Dimethyl Sulfoxide Reductase from Rhodobacter sphaeroides. J. Am. Chem. Soc. 118, 1113-1117.

32. Kutzler, F. W., Scott, R. A., Berg, J. M., Hodgson, K. O., Doniach, S., Cramer, S. P., and Chang, C. H. (1981) Single-crystal polarized $\mathrm{X}$-ray absorption spectroscopy. Observation and theory for thiomolybdate(2-). J. Am. Chem. Soc. 103, 6083-6088.

33. Jacobson, B. L., Chae, Y. K., Markley, J. L., Rayment, I., and Holden, H. M. (1993) Molecular structure of the oxidized, recombinant, heterocyst [2Fe-2S] ferredoxin from Anabaena 7120 determined to 1.7-A resolution. Biochemistrv 32, 6788-6793

34. Morales, R., Charon, M. H., Hudry-Clergeon, G., Petillot, Y. Norager, S., Medina, M., and Frey, M. (1999) Refined X-ray structures of the oxidized, at $1.3 \mathrm{~A}$, and reduced, at $1.17 \mathrm{~A},[2 \mathrm{Fe}-$ $2 \mathrm{~S}]$ ferredoxin from the cyanobacterium Anabaena PCC7119 show redox-linked conformational changes. Biochemistry 38, 1576415773.

35. Rypniewski, W. R., Breiter, D. R., Benning, M. M., Wesenberg, G., Oh, B. H., Markley, J. L., Rayment, I., and Holden, H. M. (1991) Crystallization and structure determination to 2.5-A resolution of the oxidized [2Fe-2S] ferredoxin isolated from Anabaena 7120. Biochemistry 30, 4126-4131.

36. Cosper, N. J., Eby, D. M., Kounosu, A., Kurosawa, N., Neidle, E. L., Kurtz, D. M. J. R., Iwasaki, T., and Scott, R. A. (2002) Redox-dependent structural changes in archaeal and bacterial Rieske-type [2Fe-2S] clusters. Protein Sci. 11, 2969-2973.

37. Westre, T. E., Kennepohl, P., DeWitt, J. G., Hedman, B., Hodgson, K. O., and Solomon, E. I. (1997) A Multiplet Analysis of Fe K-Edge $1 \mathrm{~s} \rightarrow 3 \mathrm{~d}$ Pre-Edge Features of Iron Complexes. J. Am. Chem. Soc. 119, 6297-6314.

38. Mayer, J. M. (1988) Metal-oxygen multiple bond lengths: a statistical study. Inorg. Chem. 27, 3899-3903.

39. Smith, P. D., Slizys, D. A., George, G. N., and Young, C. G. (2000) Toward a Total Model for the Molybdenum Hydroxylases: Synthesis, Redox, and Biomimetic Chemistry of Oxo-thio-Mo(VI) and -Mo(V) Complexes. J. Am. Chem. Soc. 122, 2946-2947.

40. Allen, F. H., Kennard, O., and Watson, D. G. (1994) "Crystallographic databases: Search and retrieval of information from the Cambridge Structural Database”. Struct. Correl. 1, 71-110.

41. Brown, K. R., Keller, G., Pickering, I. J., George, G. N., and Winge, D. R. (2002) The Structures of the Cuprous Thiolate Clusters of the Ace1 and Mac1 Transcriptional Activators. Biochemistry 41, 6469-6467.

42. Anglin, R. J., Kurtz, D. M., Kim, S., and Jacobson, R. A. (1987) Synthesis and structure of the linear tetranuclear cluster [(MoO2S2) 2Fe2S2]4-: implications for aqueous molybdenum-iron-sulfur chemistry. Inorg. Chem. 26, 1470-1472.

43. Scheiner, A. C., Baker, J., and Andzelm, J. W. (1997) Molecular energies and properties from density functional theory: Exploring basis set dependence of Kohn - Sham equation using several density functionals. J. Comput. Chem. 18, 775-795.

44. Chhabra, S. R., He, Q., Huang, K. H., Gaucher, S. P., Alm, E. J., He, Z., Hadi, M. Z., Hazen, T. C., Wall, J. D., Zhou, J., Arkin, A. P., and Singh, A. K. (2006) Global Analysis of Heat Shock Response in Desulfovibrio vulgaris Hildenborough. J. Bacteriol. $188,1817-1828$.

45. Wall, J. D., and Krumholz, L. R. (2006) Uranium reduction. Annu. Rev. Microbiol. 60, 149-166.

46. Leonhartsberger, S., Huber, A., Lottspeich, F., and Bock, A. (2001) The hydH/G Genes from Escherichia coli code for a zinc and lead responsive two-component regulatory system. J. Mol. Biol. 307, 93-105.

47. Masters, S. L., Howlett, G. J., and Pau, R. N. (2005) The molybdate binding protein Mop from Haemophilus influenzae--biochemical and thermodynamic characterisation. Arch. Biochem. Biophvs. 439, $105-112$.

48. Wagner, U. G., Stupperich, E., and Kratky, C. (2000) Structure of the molybdate/tungstate binding protein mop from Sporomusa ovata. Structure 8, 1127-1136.

49. Mouncey, N. J., Mitchenall, L. A., and Pau, R. N. (1995) Mutational analysis of genes of the mod locus involved in molybdenum transport, homeostasis, and processing in Azotobacter vinelandii. J. Bacteriol. 177, 5294-5302.

50. Williams, C. E., White, D. J., Delarbre, L., Mitchenall, L. A., Pau, R. N., and Lawson, D. M. (1999) Crystallization and preliminary $\mathrm{X}$-ray studies on the molbindin ModG from Azotobacter vinelandii. Acta Crustallogr. Sect. D: Biol. Crvstallogr. 55, 1356-1358.

51. Berlinguette, C. P., Miyaji, T., Zhang, Y., and Holm, R. H. (2006) Precursors to clusters with the topology of the $\mathrm{P}(\mathrm{N})$ cluster of nitrogenase: edge-bridged double cubane clusters [(Tp)2Mo2Fe6S8L4]z: synthesis, structures, and electron transfer series. Inorg. Chem. 45, 1997-2007.

52. Zhang, Y., and Holm, R. H. (2003) Synthesis of a molecular Mo2Fe6S9 cluster with the topology of the PN cluster of nitrogenase by rearrangement of an edge-bridged Mo2Fe6S8 double cubane. J. Am. Chem. Soc. 125, 3910-3920.

53. Noll, M., Petrukhin, K., and Lutsenko, S. (1998) Identification of a Novel Transcription Regulator from Proteus mirabilis, PMTR, Revealed a Possible Role of YJAI Protein in Balancing Zinc in Escherichia coli. J. Biol. Chem. 273, 21393-21401.

54. Sani, R. K., Peyton, B. M., and Brown, L. T. (2001) CopperInduced Inhibition of Growth of Desulfovibrio desulfuricans G20: Assessment of Its Toxicity and Correlation with Those of Zinc and Lead. Appl. Environ. Microbiol. 67, 4765-4772.

55. Mukhopadhyay, A., Redding, A. M., Joachimiak, M. P., Arkin, A. P., Borglin, S. E., Dehal, P. S., Chakraborty, R., Geller, J. T., Hazen, T. C., He, Q., Joyner, D. C., Martin, V. J. J., Wall, J. D., Yang, Z. K., Zhou, J., and Keasling, J. D. (2007) Cell-Wide Responses to Low-Oxygen Exposure in Desulfovibrio vulgaris Hildenborough. J. Bacteriol. 189, 5996-6010.

56. Reitzer, L., and Schneider, B. L. (2001) Metabolic Context and Possible Physiological Themes of \{sigma\}54-Dependent Genes in Escherichia coli. Microbiol. Mol. Biol. Rev. 65, 422-444.

BI801773T 